\title{
Fine structure of Henneguya pilosa sp. n. (Myxozoa: Myxosporea), parasite of Serrasalmus altuvei (Characidae), in Brazil
}

\author{
Carlos Azevedo $^{1}$ and Edílson Matos $^{2}$ \\ ${ }^{1}$ Department of Cell Biology, Institute of Biomedical Sciences, and CIIMAR, University of Oporto, Lg. Abel Salazar No. 2 , \\ 4099-003 Porto, Portugal; \\ ${ }^{2}$ Laboratory of Animal Biology, Faculty of Agricultural Sciences of Pará, 66.000 Belém - PA, Brazil
}

Key words: Myxozoa, Henneguya pilosa, ultrastructure, parasite, fish

\begin{abstract}
Henneguya pilosa sp. n., a new species of myxosporean from the gill filaments of the white piranha, Serrasalmus altuvei Ramirez, 1965 (Characidae), a freshwater teleost fish collected in the Zoological Garden of the city of Teresina (Piauí), Brazil, is described from light and transmission electron microscope observations. This myxosporean produced small plasmodia (up to $0.2 \mathrm{~mm}$ in diameter), each one containing all life-cycle stages of the parasite, including numerous spores. The spores, laterally compressed, averaged $54.2(52.3-56.0) \mu \mathrm{m}$ in total length and consisted of two unequal valves adhering together along the suture line and two caudal processes. The spore body measured $21.1(20.0-23.1) \mu \mathrm{m}$ in length, 5.9 (5.5-6.3) $\mu \mathrm{m}$ in width, and $2.2(1.9-2.6) \mu \mathrm{m}$ in thickness. The two equal ellipsoidal polar capsules of 7.4 (7.1-7.6) $\mu \mathrm{m}$ long and $1.2(1.0-1.3) \mu \mathrm{m}$ wide possessed a polar filament with 11-12 (rarely 13) turns. All surfaces of the spores were covered with a tightly adherent complex network of numerous densely ramified granulo-fibrillar masses, the longest measuring $1.5 \mu \mathrm{m}$ long, observed around the caudal processes. The prevalence of infection was $30 \%$. The taxonomic affinities of this parasite with other of the same genus in freshwater South American fish species are discussed.
\end{abstract}

The class Myxosporea of the phylum Myxozoa contains numerous species, some of which are pathogens, parasitizing different fish organs and tissues (Lom 1989, Lom and Dyková 1992, Eiras 2002). Among the myxosporeans, the genus Henneguya Thélohan, 1892, which includes at least, 126 species (Lom and Dyková 1992), is one of the most important pathogens of freshwater and marine fishes. Although there are numerous detailed descriptions of species of the genus Henneguya from fishes of nearly all geographical areas, little is known about South American species, mainly the Brazilian species. These were recently listed with summarized original descriptions (Gioia and Cordeiro 1996), most of them only illustrated by light microscopical records and diagrammatic drawings of the mature spores (see Nemeczek 1926, Pinto 1928, Guimarães and Bergamin 1934, Jakowska and Nigrelli 1953, Walliker 1969, Cordeiro et al. 1984).

Recently, in some Brazilian fish, mainly in the Amazonian fish, the ultrastructure of different life-cycle stages as well as other details leading to the spore identification of some Henneguya spp. have been reported (Cordeiro et al. 1984, Kent and Hoffman 1984, Azevedo and Matos 1989, 1995, 1996a, b, 2002, Rocha et al. 1992, Azevedo et al. 1997, Casal et al. 1997).

In this paper, we describe light and electron microscopical data of some life-cycle stages, including spores of a new myxosporean species.

\section{MATERIALS AND METHODS}

Spherical whitish cysts located in the gill filaments and surrounding host tissues bearing plasmodia were removed from 30 examined freshwater white piranha Serrasalmus altuvei Ramirez, 1965 (Characidae) (Brazilian common name "Piranha branca") (prevalence of 30\%) collected in the Zoological Garden of the city of Teresina (Piauí, Northeast of Brazil) $\left(05^{\circ} 05^{\prime} 21^{\prime \prime} \mathrm{S}, 42^{\circ} 48^{\prime} 07^{\prime} \mathrm{W}\right)$. Fresh isolated spores obtained directly from the sporogonic plasmodia, typically situated in close contact with the skeletal structure of the primary gill lamellae, were observed using Nomarski differential interference contrast (DIC) optics.

For transmission electron microscopy (TEM), small fragments of the tissues containing plasmodia were fixed in $3 \%$ glutaraldehyde in $0.2 \mathrm{M}$ sodium cacodylate buffer $(\mathrm{pH}$ 7.2-7.4) for $10 \mathrm{~h}$ at $4^{\circ} \mathrm{C}$, washed in the same buffer for $10 \mathrm{~h}$ at $4^{\circ} \mathrm{C}$ and post-fixed in $2 \%$ osmium tetroxide buffered in the same solution for $2 \mathrm{~h}$ at the same temperature. After dehydration in an ethanol series and propylene oxide, the fragments were embedded in Epon. Semithin sections were stained with methylene blue and ultrathin sections were contrasted with both aqueous uranyl acetate and lead citrate and observed in a JEOL 100CXII TEM operated at $60 \mathrm{kV}$.

\section{RESULTS}

Henneguya pilosa sp. n.

Figs. 1-10

Vegetative stages. Whitish, spherical to ellipsoidal plasmodia, up to $0.2 \mathrm{~mm}$ in diameter, were found in close contact with the surrounding tissues of the skeletal structure of the gills. Development was asynchronous. 


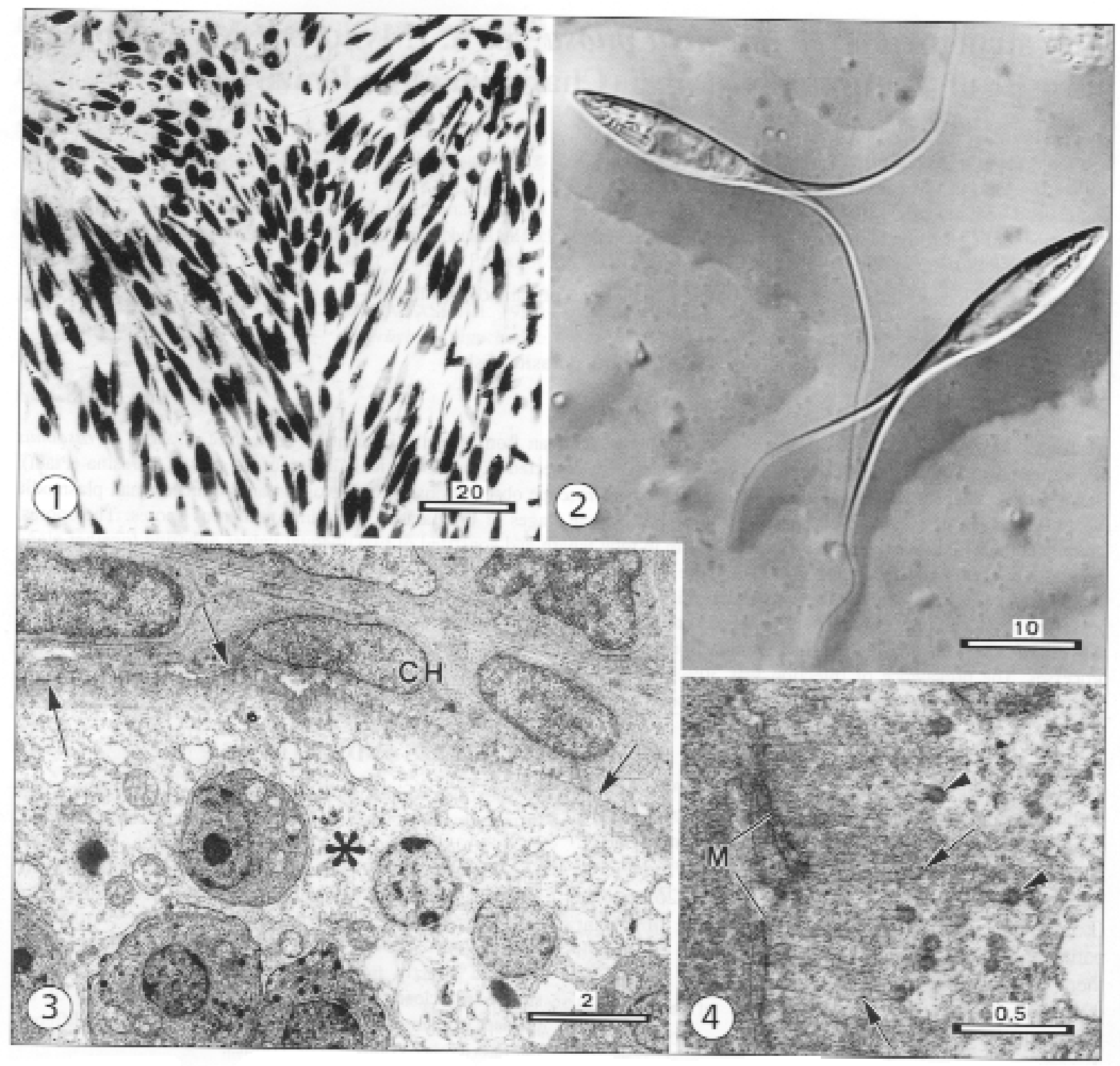

Figs. 1-4. Henneguya pilosa sp. n. Some light microscopical (Figs. 1, 2) and ultrastructural (Figs. 3-4) aspects. Fig. 1. Semithin section of a plasmodium showing numerous spores sectioned in different planes. Fig. 2. Spores observed using DIC optics. Fig. 3. The plasmodium wall showing the limiting membrane (arrows) in contact with the cells of the host $(\mathrm{CH})$. Internally $(*)$, some life-cycle stages are visible. Fig. 4. Periphery of the plasmodium showing its limiting membrane (M) and numerous pinocytotic channels (arrows) and pinocytotic vesicles (arrowheads). Length of scale bars (white parts) in $\mu \mathrm{m}$.

The plasmodia contained different stages of the generative cells and early sporogonic cells in the cortical zone and, more internally, immature and mature spores (Fig. 1). Internal to the plasma membrane of the plasmodia was a layer, $2 \mu \mathrm{m}$ thick, containing numerous pinocytotic channels, and within this was the general cytoplasm of the ectoplasm with nuclei and mitochondria (Fig. 3). The pinocytotic channels terminated internally in pinocytotic vesicles coated with electrondense material (Fig. 4). The middle zone of the endoplasm contained generative cells and cell aggregates representing early stages (sporonts and sporoblasts) of spore development (Figs. 3, 5). Generative cells and the earliest stages of sporogenesis were spherical, ranged from 2.5 to $4.7 \mu \mathrm{m}$ in diameter, and were delimited by two unit membranes (Figs. 3, 5). They contained some mitochondria and spherical to ellipsoidal nucleus, generally with a central nucleolus (Fig. 3). The central core of the plasmodia contained only mature spores. 
Azevedo, Matos: Ultrastructure of Henneguya pilosa sp. n.

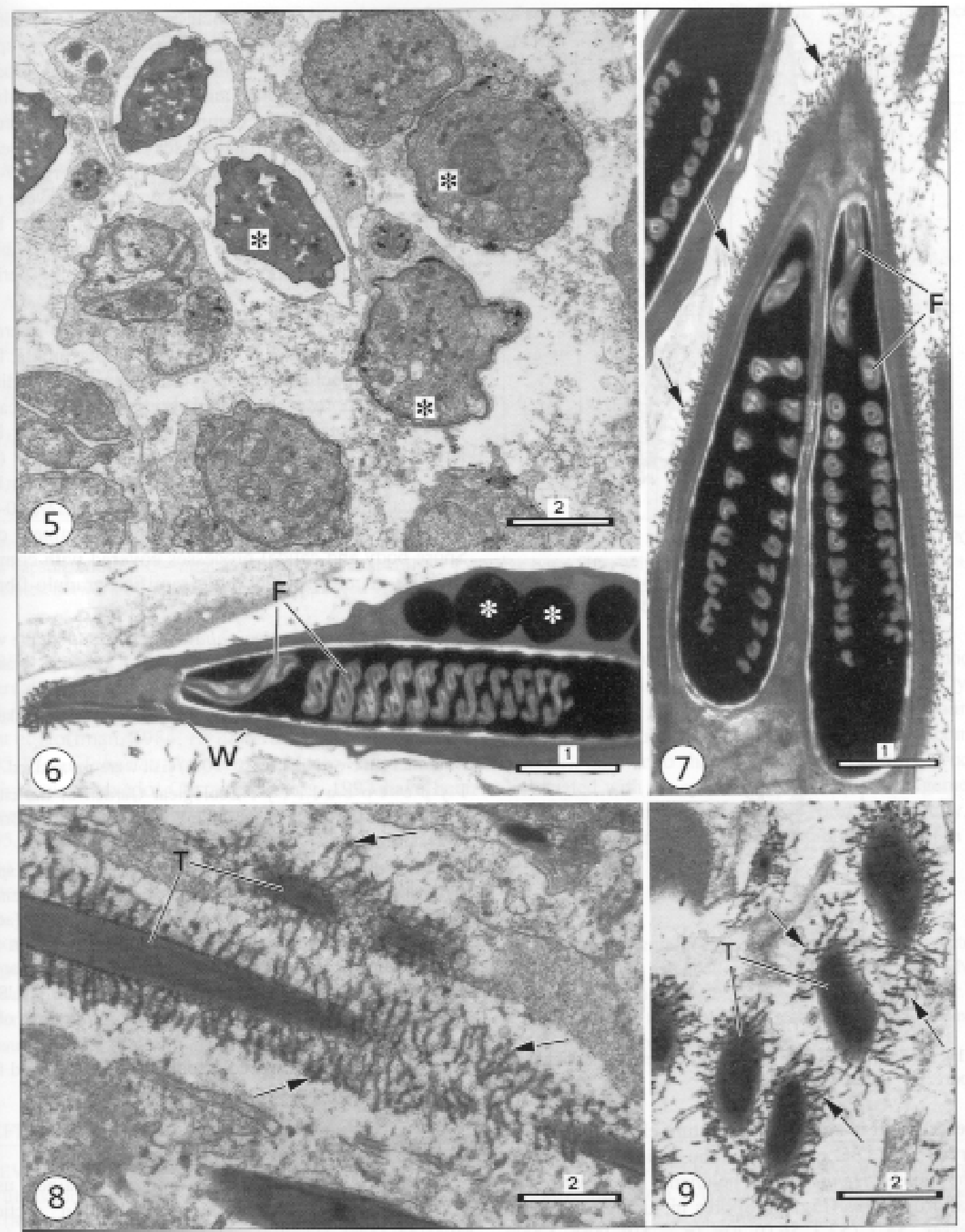

Figs. 5-9. Henneguya pilosa sp. n. Some ultrastructural aspects. Fig. 5. Internal region of a plasmodium with immature spores $(*)$, some of which show the valvogenic cells and the beginning of the valves and suture line. Fig. 6. Longitudinal ultrathin section of the apical region of the spore, showing the polar capsule and the polar filament (F). Some electron-dense spherical inclusions (*) are located between the capsule and the valve wall (W). Fig. 7. Longitudinal section of the apical region of the spore, showing the polar capsules and the organisation of different sections of the polar filament (F). On the periphery of the valves is a network of numerous densely ramified granulo-fibrillar masses (arrows). Fig. 8. Longitudinal section of the caudal processes (T), showing the dense covering of granulo-fibrillar masses (arrows) attached to the caudal processes. Fig. 9. Transverse sections of the tapering caudal processes (T), showing the attached covering network of densely ramified granulofibrillar masses (arrows), adhering to the periphery of the caudal processes. Length of scale bars (white parts) in $\mu \mathrm{m}$. 


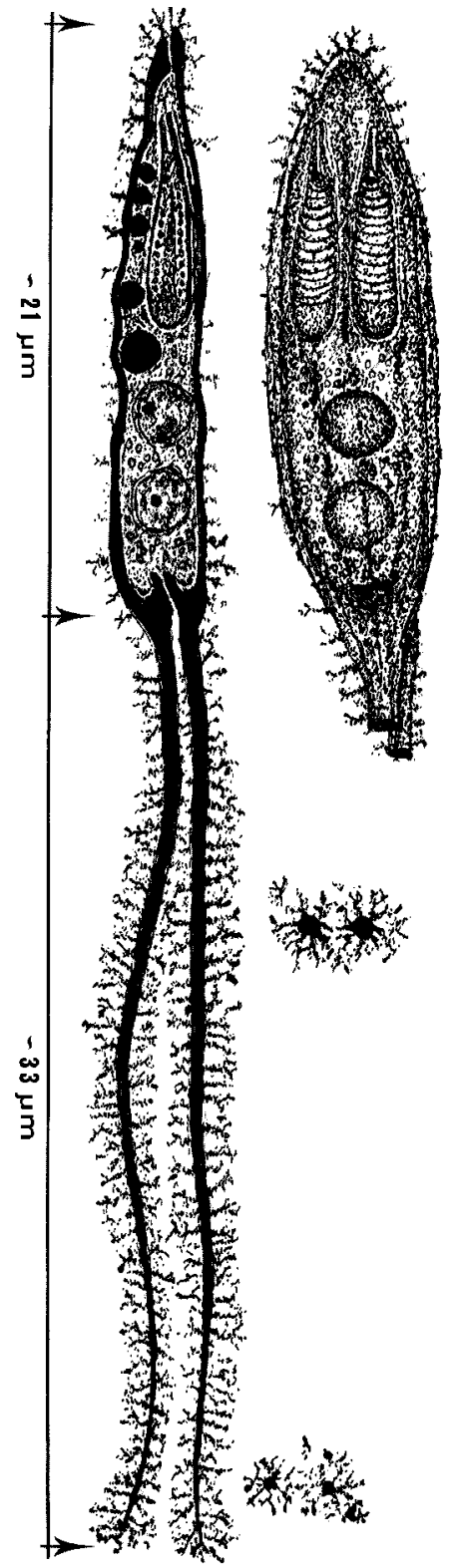

Fig. 10. Henneguya pilosa sp. n. Semischematic drawing of the spore.

Description of spores. Free mature ellipsoidal spores observed with DIC optics have the typical morphology of the genus Henneguya Thélohan, 1892 with two caudal projections (Fig. 2). Spores including the caudal processes, $54.2(52.3-56.0) \mu \mathrm{m}(\mathrm{n}=50)$ long. Spore body $21.1(20.0-23.1) \mu \mathrm{m}(\mathrm{n}=50)$ long by $5.9(5.5-$ 6.3) $\mu \mathrm{m}(\mathrm{n}=30)$ wide and $2.2(1.9-2.6) \mu \mathrm{m}(\mathrm{n}=25)$ thick. Valves asymmetrical and thin, each tapering to caudal process $33.1(30.5-34.9) \mu \mathrm{m}(\mathrm{n}=25)$ long (Fig. 2). Polar capsules elongate, $7.4(7.1-7.6) \mu \mathrm{m}(\mathrm{n}=25)$ long by $1.2(1.0-1.3) \mu \mathrm{m}(\mathrm{n}=20)$ wide, located at anterior end of spore body. Polar filaments with 11-12 coils (rarely 13 coils) (Figs. 6, 7). Coils, surrounded by dense material, occupy approximately $3 / 4$ of anterior portion of total length of polar capsules. Basal region of polar capsules electron-dense (Figs. 6, 7). Mature spores with electron-dense spherical inclusions located between polar capsules and valves (Fig. 6). Mature spores covered with complex network of densely ramified granulo-fibrillar masses in form of beaded threads connected by very fine fibrils (Figs. 7-10). These masses, measuring up to $1.5 \mu \mathrm{m}$ long, were more prominent on caudal processes than on spore body (Figs. 9-10). In favourable sections, it was possible to observe fibrils in contact with membrane of pericyte (Fig. 9).

Diagnosis. Pinocytotic channels terminate internally in pinocytotic vesicles at the surface of plasmodia. Lifecycle stages, including spores, in the same plasmodium.

Mature spores: ellipsoidal body with two caudal processes. Total length $54.2(52.3-56.0) \mu \mathrm{m}$, body length 21.1 (20.0-23.1) $\mu \mathrm{m}$, and body width 5.9 (5.56.3) $\mu \mathrm{m}$. Caudal processes 31.1 (30.5-34.9) $\mu \mathrm{m}$ long. Polar capsules 7.4 (7.1-7.6) $\mu \mathrm{m}$ long and $1.2(1.0-1.3)$ $\mu \mathrm{m}$ wide, with 11-12 (rarely 13) polar filament coils. Spore body and caudal processes covered with complex network of numerous densely ramified granulo-fibrillar masses.

T y p e h o s t: Serrasalmus altuvei Ramirez, 1965, the white piranha (Brazilian common name "piranha branca") (Characidae, Characiformes).

$\mathrm{S}$ i t e o f i n f e $\mathrm{ct}$ i o $\mathrm{n}$ : Tissues surrounding skeletal structures of the gills.

Pre va le n c e : Nine of $30(30 \%)$ fish were parasitized.

$\mathrm{T}$ y p e 1 o c a $1 \mathrm{it} \mathrm{y}$ : Zoological Garden of the city of Teresina $\left(05^{\circ} 05^{\prime} 21^{\prime \prime} \mathrm{S}, 42^{\circ} 48^{\prime} 07^{\prime \prime} \mathrm{W}\right)$ (Northeast of Brazil), Piauí, Brazil.

$\mathrm{S} p$ e c i m e n s d e p o s i t e d: Glass slides with spores were deposited in the Institute of Parasitology, Academy of Sciences of the Czech Republic, České Budějovice (accession numbers H-PM-067, H-PM-068) and in the International Protozoan Type Slide Collection at the Smithsonian Institution, Washington, D.C., USA (USNM accession number H2027071) and in the collection of the senior author.

E t y m o 1 o g y : The specific epithet "pilosa" derived from the Latin pilosus/pilosa that means "with hairs".

\section{DISCUSSION}

Observations of the mature spores, obtained using Nomarski optics and examining ultrathin sections, revealed some morphological similarities to spores of different species of the genus Henneguya described previously (Lom 1989, Lom and Dyková 1992) and, in particular, to Henneguya species reported in teleosts from the Amazon River and from other regions of South America (Table 1). However, when comparing these and other previously studied species of this genus with the results obtained, there is a great variance both in the morphology and dimensions of the spores, mainly among the Brazilian species (Table 1). 
Table 1. Comparative measurements (in $\mu \mathrm{m}$ ) and other characters of spores of the Henneguya Thélohan, 1892 species described from South American fishes.

\begin{tabular}{|l|c|c|c|c|c|c|c|c|c|}
\hline $\begin{array}{l}\text { Henneguya } \text { spp. } \\
\text { (authors) }\end{array}$ & $\mathrm{TL}$ & $\mathrm{BL}$ & $\mathrm{BW}$ & $\mathrm{TaL}$ & $\mathrm{PCL}$ & $\mathrm{PCW}$ & $\mathrm{FC}$ & $\mathrm{VT}$ & Sh \\
\hline $\begin{array}{l}\text { H. theca } \\
\quad \text { (Kent and Hoffman 1984) }\end{array}$ & 48.0 & 24.8 & 3.5 & 23.2 & 11.1 & 1.4 & - & equal & + \\
$\begin{array}{l}\text { H. pisciforme } \\
\quad \text { (Cordeiro et al. 1984) }\end{array}$ & 20.4 & 10.0 & 6.1 & 10.7 & 4.36 & 1.70 & - & - & - \\
$\begin{array}{l}\text { H. amazonica } \\
\quad \text { (Rocha et al. 1992) }\end{array}$ & 59.3 & 13.9 & 5.7 & 45.4 & 3.3 & 1.5 & 6 & - & - \\
$\begin{array}{l}\text { H. adherens } \\
\quad \text { (Azevedo and Matos 1995) }\end{array}$ & 32.3 & 12.4 & 5.8 & 20.5 & 3.1 & 1.2 & $3-4$ & unequal & + \\
$\begin{array}{l}\text { H. malabarica } \\
\quad \text { (Azevedo and Matos 1996a) }\end{array}$ & 28.3 & 12.6 & 4.8 & 17.1 & 3.7 & 1.8 & $6-7$ & equal & + \\
$\begin{array}{l}\text { H. testicularis } \\
\quad \text { (Azevedo et al. 1997) }\end{array}$ & 27.5 & 14.0 & 6.5 & 13.5 & 9.0 & 2.0 & $12-13$ & unequal & + \\
$\begin{array}{l}\text { H. striolata } \\
\quad \text { (Casal et al. 1997) }\end{array}$ & 42.2 & 15.8 & 5.3 & 25.9 & 6.8 & 1.2 & $13-14$ & equal & + \\
$\begin{array}{l}\text { H. curimata } \quad \text { (Azevedo and Matos 2002) } \\
\text { H. pilosa } \\
\quad \text { (Present study) }\end{array}$ & 35.4 & 16.6 & 6.2 & 19.1 & 6.5 & 1.2 & $10-11$ & equal & - \\
\hline
\end{tabular}

Abbreviations: TL - total length; BL - body length; BW - body width; TaL - tail length; PCL - polar capsule length; PCW polar capsule width; FC - number of polar filament coils; VT - valve type; Sh: + with surrounding homogeneous sheath, ++ with a complex network of numerous densely ramified granulo-fibrillar masses, - no references.

With respect to Henneguya species containing an external homogeneous sheath surrounding the spore body and caudal processes, only the spores of $H$. theca Kent et Hoffman, 1984, H. adherens Azevedo et Matos, 1995, H. malabarica Azevedo et Matos, 1996, and H. testicularis Azevedo, Corral et Matos, 1997 have been described (Kent and Hoffman 1984, Azevedo and Matos 1995, 1996a, Azevedo et al. 1997). Among the Henneguya species, only in the spores of $H$. striolata Casal, Matos et Azevedo, 1997 occurred the external organisation that resembles the one described in $H$. pilosa, although the granulo-fibrillar masses in $H$. pilosa are longer and more organized into a complex ramified network than those in $H$. striolata. These two species differ in spore size and shape, arrangement of the polar capsules, polar filament coils and host specificity (Table $1)$.
Our results were also compared with other previously described species of the same genus (Lom and Dyková 1992). We did not find any reference to a surrounding sheath that is ultrastructurally organized as a complex network similar to that in $H$. pilosa. So, this structure, associated with the spore size and shape, arrangement of the polar filaments coils, and host specificity, are sufficient arguments for the establishment of a new species.

Acknowledgements. This study was partially supported by the A. Almeida Foundation (Porto, Portugal) and CNPq Brazil. The authors thank Ms. Laura Corral and Mr. João Carvalheiro for their excellent technical assistance and Dr. Carla Silva for computer assistance.

\section{REFERENCES}

AZEVEDO C., CORRAL L., MATOS E. 1997: Light and ultrastructural data on Henneguya testicularis n. sp. (Myxozoa, Myxobolidae), a parasite from the testis of the Amazonian fish Moenkhausia oligolepis. Syst. Parasitol. 37: 111-114.

AZEVEDO C., MATOS E. 1989: Some ultrastructural data on the spore development in a Henneguya sp. parasite of the gill of a Brazilian fish. Parasitol. Res. 76: 131-134.

AZEVEDO C., MATOS E. 1995: Henneguya adherens n. sp. (Myxozoa, Myxosporea), parasite of the Amazonian fish, Acestrorhynchus falcatus. J. Euk. Microbiol. 42: 515-518.
AZEVEDO C., MATOS E. 1996a: Henneguya malabarica sp. nov. (Myxozoa, Myxobolidae) in the Amazonian fish Hoplias malabaricus. Parasitol. Res. 82: 222-224.

AZEVEDO C., MATOS E. 1996b: Light and electron microscopic study of a myxosporean, Tetrauronema desaequalis n. sp. (fam. Tetrauronematidae), from an Amazonian fish. J. Parasitol. 82: 288-291.

AZEVEDO C., MATOS E. 2002: Fine structure of the myxosporean, Henneguya curimata n. sp., parasite of the Amazonian fish, Curimata inornata (Teleostei, Curimatidae). J. Euk. Microbiol. 49: 197-200. 
CASAL G., MATOS E., AZEVEDO C. 1997: Some ultrastructural aspects of Henneguya striolata sp. nov. (Myxozoa, Myxosporea), a parasite of the Amazonian fish Serrasalmus striolatus. Parasitol. Res. 83: 93-95.

CORDEIRO N.S., ARTIGAS P.T., GIÓIA I., LIMA R.S. 1984: Henneguya pisciforme $\mathrm{n}$. sp., mixosporídeo parasito de brânquias do lambari Hyphessobrycon anisitsi (Pisces, Characidae). Mem. Inst. Butantan 47/48: 61-69.

EIRAS J.C. 2002: Synopsis of the species of the genus Henneguya Thélohan, 1892 (Myxozoa: Myxosporea: Myxobolidae). Syst. Parasitol. 52: 43-54.

GIOIA I., CORDEIRO N.S. 1996: Brazilian myxosporidians' check-list (Myxozoa). Acta Protozool. 35: 137-149.

GUIMARÃES J.R.A., BERGAMIN F. 1934: Henneguya santae sp. n. Um novo mixosporídeo parasito de Tetragonopterus sp. Rev. Ind. Anim. 10: 110-113.

JAKOWSKA S., NIGRELLI R.F. 1953: The pathology of myxosporidiosis in the electric eel, Electrophorus electricus (Linnaeus), caused by Henneguya visceralis and Henneguya electrica spp. nov. Zoologica 38: 183-191.

KENT M.L., HOFFMAN G.L. 1984: Two new species of Myxozoa, Myxobolus inaequus sp. n. and Henneguya

Received 30 April 2002 theca sp. n. from the brain of a South American knife fish, Eigenmannia virescens (V.). J. Protozool. 31: 91-94.

LOM J. 1989: Phylum Myxozoa. In: L. Margulis, J.O. Corliss, M. Melkonian and D.J. Chapman (Eds.), Handbook of Protoctista. Jones and Bartlett Publishers, Boston, pp. 3652.

LOM J., DYKOVÁ I. 1992: Protozoan Parasites of Fishes. Developments in Aquaculture and Fisheries, Vol. 26. Elsevier, Amsterdam, 328 pp.

NEMECZEK A. 1926: Beiträge zur Kenntnis der Myxosporidienfauna Brasiliens. Arch. Protistenkd. 54: 137-150.

PINTO C. 1928: Myxobolus noguchii, M. stokesi e Henneguya iheringi, espécies novas de myxosporídeos de peixes de água doce do Brasil. Bol. Biol. 12: 41-43.

ROCHA E., MATOS E., AZEVEDO C. 1992: Henneguya amazonica n. sp. (Myxozoa, Myxobolidae) parasitizing the gills of Crenicichla lepidota Heckel, 1840 (Teleostei, Cichlidae) from the Amazon river. Eur. J. Protistol. 28: 273-278.

WALLIKER D. 1969: Myxosporidea of some Brazilian freshwater fishes. J. Parasitol. 55: 942-948.

Accepted 10 September 2002 